\section{Tomislav Rakić ${ }^{1}$}

TommyR Corptex LLC Leskovac

Snežana Živković ${ }^{2}$

University of Niš, Faculty of occupational safety in Niš
SCIENTIFIC REVIEW ARTICLE

DOI:10.5937/ekonomika1704061R

Received May, 01, 2017

Accepted: Jun, 02, 2017

\title{
HIERARCHY OF NEEDS AND CORRELATION CONNECTIONS AS AN IMPORTANT ELEMENT OF SUCCESSFUL EMPLOYEES' MOTIVATION ${ }^{3}$
}

\begin{abstract}
Motivating the employees is one of the main tasks of human resource management and a very important factor of their professional development. Providing safe working conditions is a complex process that is determined not only by the specific individual motivation for safety and health at work, but also by organization of the working processes, organizational culture and other factors. Supposing that personal motivation and environmental motivation are not universal, there has been issued an extensive study of all relevant factors of motivation for working and motivation for safe operating in the company Port of Adria JSC Bar. The aim of this paper is to determine the order of motivating factors for workers that have the greatest impact on respondents and which are the most significant as far as the employees'motivation is concerned. By a detailed analysis of data and determining the hierarchical relationship among the responses by various criteria, there has been formed a final model of considering collective attitude of the organization based on the survey questions. The most important conclusion of the study indicates that the introduction of advanced technologies and modernization of working funds, combined with increasing of salary and fairer distribution of income, have the greatest impact on workers 'sense that the organization shows respect for the results of their work.
\end{abstract}

Key words: motivating the employees, human resource management, hierarchy of needs, collective attitude

JEL classification: J24, J53, D22

\section{ХИЈЕРАРХИЈА ПОТРЕБА И КОРЕЛАЦИОНЕ ВЕЗЕ КАО БИТАН ЕЛЕМЕНТ УСПЕШНЕ МОТИВАЦИЈЕ ЗАПОСЛЕНИХ}

\footnotetext{
Апстракт

Мотиващија запослених је један од главних задатака менащмента људским ресурсима и веома важан фактор за професионални развој запослених. Остваривање безбедних услова рада представља комплексан процес који је

${ }^{1}$ tomislav.rakic@gmail.com

${ }^{2}$ snezana.zivkovic@znrfak.ni.ac.rs

${ }^{3}$ Acknowledgements: The research presented in this paper was financed by the Ministry of Science and Technological Development of Serbia within the projects III 43014 and III 42006.
} 
одређен специфичном индивидуалном мотивацијом за безбедност и здравље на раду, тако и организацијом процеса рада, организационом културом и другим факторима. Полазећи од тога да лична и срединска мотивација нису унивезалне, обављено је обимно истраживање свих релевантних фактора мотивачије за рад и мотивације за безбедан рад у предузећу Port of Adria АД Бар. Циь рада је да утврди редослед мотивачионих фактора за раднике који имају највећи утицај за испитанике и који су најзначајнији када је у питању мотивација радника. Детаљьом обрадом података и одређивањем хијерархијских односа између одговора по различитим критеријумима, формиран је коначан модел за разматрағе колективног става организачије по анкетним питанима. Најважнији закључак студије указује да увођење савременије технологије и модернизачија средстава за рад у комбинацији са повећањем зарада и праведније расподеле дохотка имају највећи утицај на осећај радника да организащија показује поштовање према резултатима њиховог рада.

Кључне речи: мотивачија запослених, управљање људским ресурсима, хијерархија потреба, колективни став

\section{Introduction}

Evaluation of work and an adequate remuneration of employees and managers are crucial for both short-term and long-term success of any company. In a modern economy, based on the knowledge about the system of evaluation, managers' attention is focused on long-term consequences of their actions by encouraging them to follow the implementation of effective strategies and to get informed about the results of assessment and development of organizational performance (Kaplan and Norton, 1996; Lusthas et al., 2002; Bowlby, 2011).

Motivation and employees' satisfaction are key areas of interest in the management of human resources, because only providing a good motivation system helps the organization to increase its competitive ability and the value of the company. Relationship between the performance and reward is an important factor of the employees' motivation and is considered to be a crucial factor of system effectiveness (Burnley, Henle and Widener, 2009). Companies that haven't developed a strategy for motivating and rewarding (Arnolds and Vener, 2007), have a bad working atmosphere, lack of reliability and trust, employees feel bad, and this inevitably leads to stagnation and decline. Modern organization, based on knowledge, assumes that employees should be motivated to do more than what their working task is (Williamson et al., 1997; Cavazza and Serpe, 2009). In this case, a tendency to achieve the greatest possible individual motivation can be achieved only if the following conditions are fullfiled (Tissan, Andriesen and Depre, 2006): if an individual believes that what he does has certain results; if an individual feels that the result is attractive and if an individual believes that it is possible to achieve the desired effect. Certain human behaviors are determined by internal psychological triggers that force them to do something, and therefore, the result of an individual depends not only on his knowledge, abilities, skills, but also on how motivated he is. Thus, it is very important that managers understand the complexity of the personality of each person and to select, adapt and apply appropriate motivational techniques and processes (Neal and Griffin, 2004; Christian et al., 2009). 
Motivation theories give us a specific view of motivation in general, also including the motivation to work, and they are focused on trying to explain why some people accept motivators such as salary, promotion, job security, etc., while the others avoid them, and what makes something a goal and which goals people want to reach.

There are several theories of motivation. The basic division of theories of motivation would be into the original theories of motivation and the modern theories of motivation. The group of the original theories of motivation includes:

Douglas McGregor's Theory X / Y. McGregor (1960) claims that the managerial styles of management are divided into Theory X and Theory Y. According to the Theory $\mathrm{X}$, workers dislike work, avoid it, and they need constant supervision, while Theory $\mathrm{Y}$ stands for a completely opposite attitude of the employees. Theory $\mathrm{X}$ represents the "hard" (hard) model of governance, while the Theory Y represents a "softer" (soft) management model. Although they are essentially opposite, the theories are intertwined in practice.

Hierarchy of needs theory by Abraham Maslow. Maslow (1943) presented his theory of a specific sequence in the development of needs which explains that "higher" needs could not be expressed, unless the "lower" needs are satisfied. Maslow discovered that the people in the organization are motivated by five groups of hierarchically arranged needs (Figure 1). These five groups of needs are:

- Physiological needs are the natural needs that each individual has as a biological entity (eg. food, home...). The employees satisfy these needs in the company with salaries that they receive for their work;

- The needs for security include physical security and safety of the workplace, but also the psychological security from the different types of stress, frustration, attacks, etc.;

- The needs for love and belonging are related to one's desire to be accepted and loved by the collective, and to feel as a full member of this team. This group of needs derives from the man's character as a social being;

- The need for respect. For human beings it is not enough to be just accepted and loved by the people in their environment. They need to be respected by other people, or even by themselves (self-esteem). This need includes the need for status and power;

- $\quad$ The need for self-realization. This is the last in the hierarchy of human needs by Maslow. When all other kinds of needs are accomplished, human beings have the need to realize all their capabilities and potentials at their disposal. The need for self-realization refers to one's desire to succeed in what he is doing and to use the skills, talents and knowledge that he possesses.

The hierarchical arrangement of these needs means that there is an order of their satisfaction. This practically means that the needs of "higher" order cannot be met unless the needs of "lower" order i.e. the ones that are closer to the base of the hierarchical pyramid, are met. Physiological needs must be satisfied first, and if they are not satisfied, the satisfaction of other, higher needs is not possible. In other words, if an employee receives a small salary which he cannot satisfy his physiological needs, then he can hardly even think of meeting the needs of belonging, respect and self-realization. It should be noted that once the needs are met, they cease to be a source of motivation and there appears to be a need of a higher level. 
So, when there is a satisfactory level of earning to meet the employees' basic physiological needs and security needs, they no longer represent a source of motivation.

Herzberg's theory of "hygienic" motivation (Herzberg, Mausner and Snyderman, 1959) generally represents a modified Maslow's approach to needs. In their research they pointed out the two-factor theory of motivation. In his theory of 'hygienic' motivation, Frederick Herzberg suggests that the factors of satisfaction at work and motivation are intrinsically linked, while the secondary factors should be associated with dissatisfaction at work (Robbins, 2003).

Figure 1: Hierarchy of needs according to Abraham Maslow

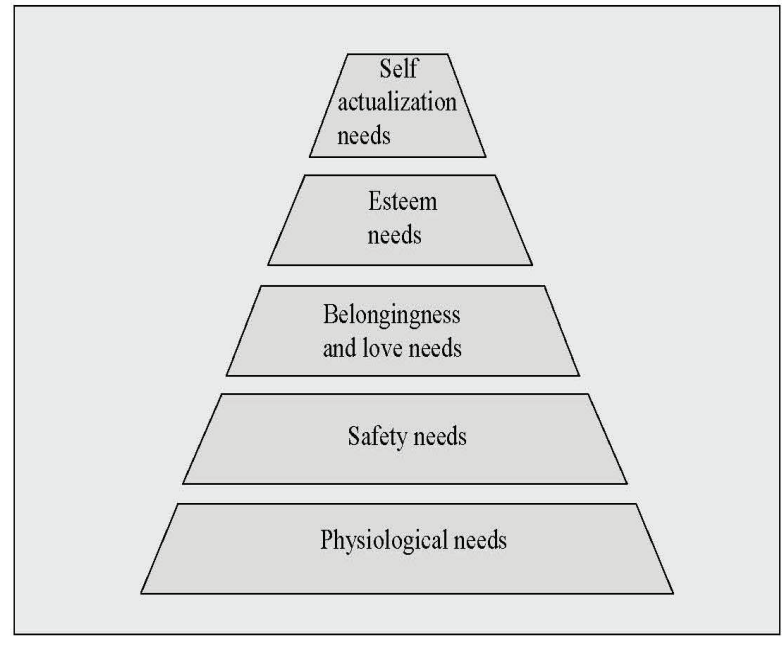

Source: Own source

Alderfer's model of needs, known as ERG, unlike Maslow's model, doesn't contain the assumption of the hierarchical relationship of human needs. Alderfer (1972) only claims that people in organizations are driven by three types of needs:

- Existential needs (E - Existence);

- The need for relatedness(R- Relatedness);

- Growth, development needs (G- Growth).

Existential needs correspond to Maslow's basic needs, the needs to connect are the same as the needs for belonging and love, while development needs are related to people's desire to grow, learn new things, improve their skills, work interesting and challenging jobs and achieve results. This theory has similarities and differences in relation to the theory of Maslow's hierarchy of needs. The idea of this theory to identify the needs that drive human activity is the same as Maslow's idea. Also, a great similarity in the definition of need is notable. However, there are significant differences, such as those relating to the way in which the individual needs become active as motivators for individuals.

In the group of contemporary theories of motivation, the following can be classified:

David McClelland proposed a Three Needs Theory, which says that there are three acquired, not congenital, properties which are the main motif in the work. McClelland (1966) has differentiated three types of needs that people satisfy in organizations. These are: 
- The need for pooling (nAff- need for affiliation);

- The need to achieve success (nAch-need for achievement);

- The need to achieve power (nPow-need for power).

The needs for belonging correspond to the needs identified in other theories of motivation. What is new in McClelland's theory is the need for achievement and power. The need for achievement represents one's need to succeed in what he does. It is important to emphasize that the need for achievement can be consciously planned to develop in children during their upbringing. McClelland even claimed that this need can be strengthened even in adults. The need for those he saw in the fact that the need for achievement is particularly important for entrepreneurs who create new values in the economy. He even claimed that there is a positive correlation between the degree of economic development of a country and the percentage of people who express the need for achievements in that country.

The need for power is also a novelty that is introduced into the McClelland's theory of motivation. He found that people have a legitimate need to exercise influence over other people. In the American national culture, this need is often discredited since it is considered that the power to wish something is bad and immoral. McClelland even found that most people have this need and that it is particularly important to those in managing positions.

Goal setting theory explains that setting the goals is the most important part of encouraging human activity (Latham and Locke, 1979). The basic idea of this theory is that goal setting is a mechanism of motivation because it puts one in the position to compare his skills with those that are required to achieve the target. Setting goals motivates people much more than telling them: "Do your best". This requirement is very vague because people often do not know what it is and how to "do their best". When they have a clear objective to be achieved, they know exactly how much effort should be invested in its implementation. The theory is checked, and in practice it provides that a target in front of an individual or group actually increases the level of motivation to work.

There are three basic messages for managers that can be derived from the theory of goal setting:

- Any individual or group in the organization should always have a set objective of their activities as well as a very clear, specific goal. It has also been found that people work better if the goal is specific and quantified;

- The objectives should be set so as to be very difficult to achieve but still achievable. Impracticable and too easily achievable objectives demotivate people;

- $\quad$ The employees must always get a feedback on achieving their goals. People are more motivated if they know how to achieve the set goals.

Wroom's expectancy theory (Expectancy Theory) is based on the assumption that most of the behavior of employees in organizations is the result of their free choice. Wroom (1964) observes the process of motivation as a cognitive process in which the individual rationally and freely decides (makes choices) whether and what behavior to apply depending on his assessment of the effects of these behaviors. So, whether an individual will be motivated or not depends on his assessment of the efforts to be made in his behavior, the effects of that effort and the expected reward. 
Employees' motivation is described as resulting from three factors: the expectation of the effort that someone makes in his behavior leads to results of the first order (performance), the results instruments of the first order and evaluating the possibility of their leading to the results of the second order and valence, or preference for results of the second order.

\section{Methodological framework of the research}

The research sample consists of the employees of the Port of Adria JSC Bar. The research was conducted on a sample of 184 respondents. The sample comprises respondents of different business units, of different sex, age and length of service.

Professionals filled in the survey sheets at break time, before or after work.

An interview was used as the main research method which revealed subjective attitudes of the employees. The survey instrument was a modified Measuring scale for occupational safety motivation (Živković, 2008), containing 38 questions.

The following statistical methods for the processing and presentation of research were used: frequency, percentage, cumulative percentage, ranking, standard deviation, correlation coefficient, Paired sample T test, ABC diagram.

Statistical analysis was performed using the software package for statistical analysis SPSS for Windows ver. 19.0.

The survey was conducted in 2014 and 2015.

\section{Results and discussion}

Based on the results collected by a detailed survey conducted in the company Port of Adria JSC Bar and using a questionnaire with 38 questions of a modified Measuring scale for occupational safety motivation, the aim of which was to make a range of motivating factors for workers. They were processed by using ABC diagram (Rakić, 2015):

Table 1: Presented results based on data collected by questionnaire (question 38 of modified scale)

\begin{tabular}{|l|l|c|c|c|c|}
\hline \multicolumn{1}{|c|}{ No. of question } & \multicolumn{1}{|c|}{ Align by rank } & Frequency & Percent & $\begin{array}{c}\text { Cum. } \\
\text { percent }\end{array}$ & Group \\
\hline 1 organization of work & 6 salary & 1.528 & $15.10 \%$ & $15.10 \%$ & $\mathrm{~A}$ \\
\hline 2 team work & 4 job security & 1.266 & $12.51 \%$ & $27.61 \%$ & $\mathrm{~A}$ \\
\hline 3 balance & 9 benefits & 1.090 & $10.77 \%$ & $38.38 \%$ & $\mathrm{~A}$ \\
\hline 4 job security & 10 fairly rewarding & 1.062 & $10.49 \%$ & $48.87 \%$ & $\mathrm{~A}$ \\
\hline 5 communication & 3 balance & 1.060 & $10.47 \%$ & $59.35 \%$ & $\mathrm{~A}$ \\
\hline 6 salary & 2 team work & 894 & $8.83 \%$ & $68.18 \%$ & $\mathrm{~A}$ \\
\hline $\begin{array}{l}\text { 7 involving in decision-making } \\
\text { process }\end{array}$ & 1 organization of work & 892 & $8.81 \%$ & $77.00 \%$ & $\mathrm{~B}$ \\
\hline 8 training and development & $\begin{array}{l}8 \text { training and } \\
\text { development }\end{array}$ & 810 & $8.00 \%$ & $85.00 \%$ & $\mathrm{~B}$ \\
\hline 9 benefits & 5 communication & 806 & $7.96 \%$ & $92.96 \%$ & $\mathrm{C}$ \\
\hline
\end{tabular}




\begin{tabular}{|l|l|l|l|l|l|}
\hline 10 fairly rewarding & $\begin{array}{l}7 \text { involving in } \\
\text { decision-making } \\
\text { process }\end{array}$ & 712 & $7.04 \%$ & $100.00 \%$ & C \\
\hline & & 10.120 & & & \\
\hline
\end{tabular}

Figure 2: Graphiclly presented results (ABC diagram)

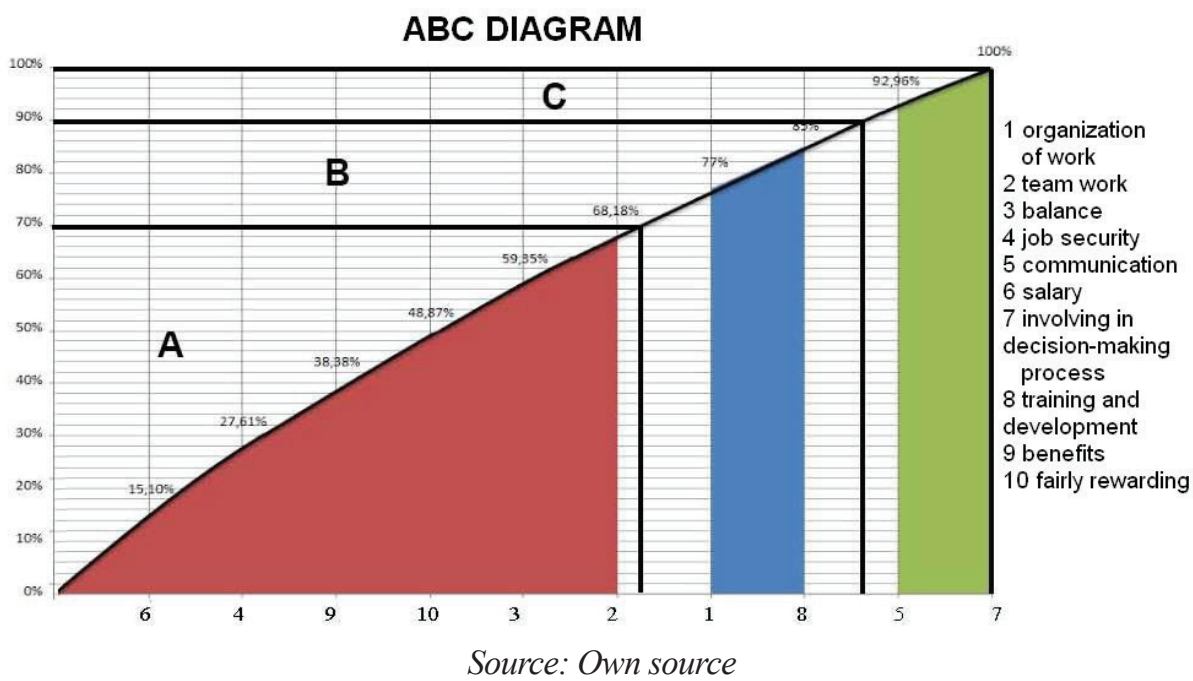

$\mathrm{ABC}$ diagram clearly shows which factors have the greatest impact on respondents. Issues that have been found in a square A have the greatest impact on employees and should be the focus of HRM. Questions from the square B are important, but they need to be considered when issues from the square A have already been solved, or, if it is impossible to satisfy all the conditions of the square A, mixing the square A and square B should be done, with the aim of costs rationalization, while the square $\mathrm{C}$ does not need a special deal at the outset, since it requires great expenses and effort, and the results are almost negligible.

Based on the results obtained by analyzing the questionnaire, with the help of $A B C$ chart, based on the theory of Maslow's hierarchy of needs, the resulting model is shown in Figure 3. 
Figure 3: Significance of satisfaction pyramid

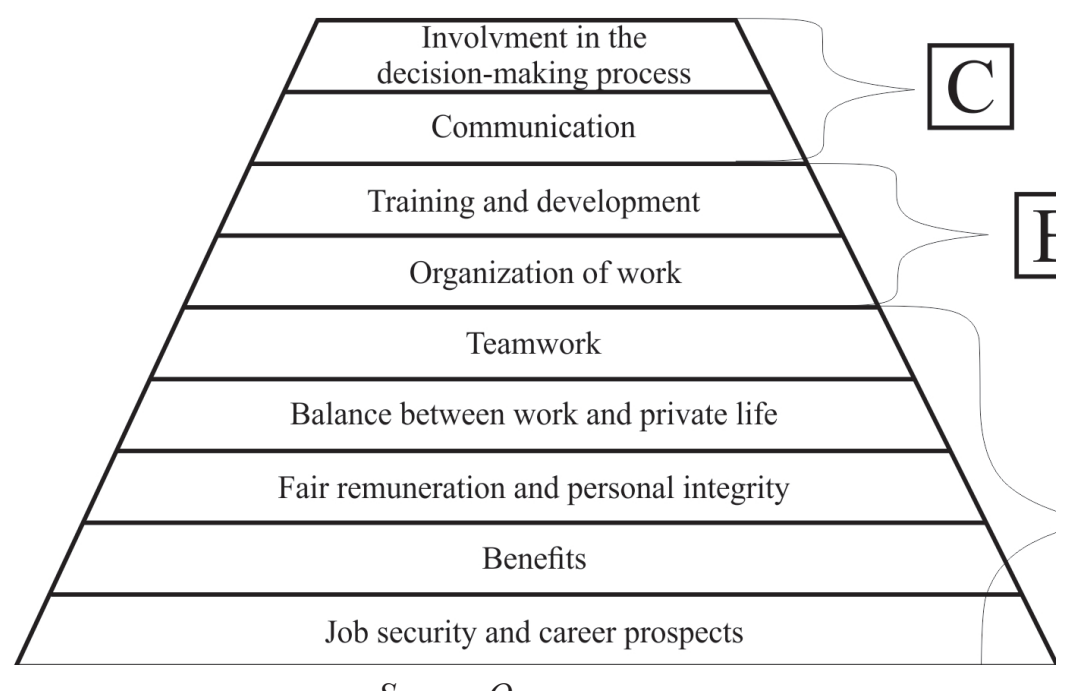

Source: Own source

Based on the Pyramid of satisfaction it is possible to draw clear conclusions about the direction in which the activities of HRM in organization should continue to go:

- The order of satisfying needs should be respected;

- The needs closer to the basis must be satisfied first, and only then to move on to a higher level;

- Considering that in this case the needs are classified into three segments, A, B and $\mathrm{C}$ (Figure 3), the needs of the segment A should be met first, then the B segment, and only in the end of the segment $\mathrm{C}$;

If it is impossible to meet adequately the needs of the segment A, since it has six, it can be mixed with the B segment, and thus achieve a costs reduction while increasing productivity.

Although they are often pointed out as very important factors of the employees' satisfaction, communication and involvement in decision-making, according to this study, have been at the bottom of the pyramid of needs, and there is no need to use funds and resources for this purpose, or at least not as long as there is even an unmet need within the segment $\mathrm{A}$ and segment $\mathrm{B}$, whose satisfaction is not very demanding.

Using a software package for statistical analysis of data SPSS, certain correlations between individual responses from the concerned questionnaire have been determined. The resulting correlation coefficients among all the variances of the questionnaire are presented in Table 2: 
Table 2: Correlation coefficients between all answers

\begin{tabular}{|c|c|c|c|c|c|c|c|c|}
\hline \multicolumn{9}{|c|}{ Correlations } \\
\hline & & VAR 001 & VAR 002 & $\begin{array}{c}\text { VAR } \\
003\end{array}$ & VAR 004 & $\begin{array}{l}\text { VAR } \\
005\end{array}$ & $\begin{array}{c}\text { VAR } \\
006\end{array}$ & $\begin{array}{c}\text { VAR } \\
007\end{array}$ \\
\hline \multirow{3}{*}{$\begin{array}{l}\text { VAR } 001 \\
\text { to increase earnings } \\
\text { and equitable } \\
\text { distributed income }\end{array}$} & $\begin{array}{c}\text { Pearson } \\
\text { Correlation }\end{array}$ & 1 & & & & & & \\
\hline & $\begin{array}{c}\text { Sig. } \\
\text { (2-tailed) }\end{array}$ & & & & & & & \\
\hline & $\mathrm{N}$ & 184 & & & & & & \\
\hline \multirow{3}{*}{$\begin{array}{l}\text { VAR } 002 \\
\text { to create a better } \\
\text { social protection } \\
\text { programs }\end{array}$} & $\begin{array}{c}\text { Pearson } \\
\text { Correlation }\end{array}$ & .039 & 1 & & & & & \\
\hline & $\begin{array}{c}\text { Sig. } \\
\text { (2-tailed) }\end{array}$ & .598 & & & & & & \\
\hline & $\mathrm{N}$ & 184 & 184 & & & & & \\
\hline \multirow{3}{*}{$\begin{array}{l}\text { VAR } 003 \\
\text { to improve social } \\
\text { protection programs }\end{array}$} & $\begin{array}{c}\text { Pearson } \\
\text { Correlation }\end{array}$ & -.037 & $.635^{* *}$ & 1 & & & & \\
\hline & $\begin{array}{c}\text { Sig. } \\
\text { (2-tailed) }\end{array}$ & .615 & .000 & & & & & \\
\hline & $\mathrm{N}$ & 184 & 184 & 184 & & & & \\
\hline \multirow{3}{*}{$\begin{array}{l}\text { VAR } 004 \\
\text { to improve } \\
\text { interpersonal } \\
\text { relations }\end{array}$} & $\begin{array}{c}\text { Pearson } \\
\text { Correlation }\end{array}$ & .113 & $.614^{* *}$ & $.627^{* *}$ & 1 & & & \\
\hline & $\begin{array}{c}\text { Sig. } \\
\text { (2-tailed) }\end{array}$ & .127 & .000 & .000 & & & & \\
\hline & $\mathrm{N}$ & 184 & 184 & 184 & 184 & & & \\
\hline \multirow{3}{*}{$\begin{array}{l}\text { VAR } 005 \\
\text { that the organization } \\
\text { shows more respect } \\
\text { for the results of } \\
\text { their workers }\end{array}$} & $\begin{array}{c}\text { Pearson } \\
\text { Correlation }\end{array}$ & .127 & $.154^{*}$ & $.207^{* *}$ & $.437^{* * *}$ & 1 & & \\
\hline & $\begin{array}{c}\text { Sig. } \\
\text { (2-tailed) }\end{array}$ & .087 & .037 & .005 & .000 & & & \\
\hline & $\mathrm{N}$ & 184 & 184 & 184 & 184 & 184 & & \\
\hline \multirow{3}{*}{$\begin{array}{l}\text { VAR } 006 \\
\text { to introduce more } \\
\text { modern technology } \\
\text { and modern means } \\
\text { of work }\end{array}$} & $\begin{array}{c}\text { Pearson } \\
\text { Correlation }\end{array}$ & .082 & $.374^{* *}$ & $.584^{* *}$ & $.567^{* * *}$ & $.221^{* *}$ & 1 & \\
\hline & $\begin{array}{c}\text { Sig. } \\
\text { (2-tailed) }\end{array}$ & .269 & .000 & .000 & .000 & .003 & & \\
\hline & $\mathrm{N}$ & 184 & 184 & 184 & 184 & 184 & 184 & \\
\hline \multirow{3}{*}{$\begin{array}{l}\text { VAR } 007 \\
\text { to give workers } \\
\text { greater } \\
\text { opportunities for } \\
\text { participation in } \\
\text { decision-making }\end{array}$} & $\begin{array}{c}\text { Pearson } \\
\text { Correlation }\end{array}$ & .130 & $.640^{* *}$ & $.731^{* * *}$ & $.719^{* * *}$ & $.391^{* *}$ & $.663^{* *}$ & 1 \\
\hline & $\begin{array}{c}\text { Sig. } \\
\text { (2-tailed) }\end{array}$ & .079 & .000 & .000 & .000 & .000 & .000 & \\
\hline & $\mathrm{N}$ & 184 & 184 & 184 & 184 & 184 & 184 & 184 \\
\hline
\end{tabular}

According to the values of correlation coefficients, the model of interdependence issues has been determined and presented in Figure 4: 
Figure 4: The starting model of interdependence survey questions, formed on the basis of correlation coefficients

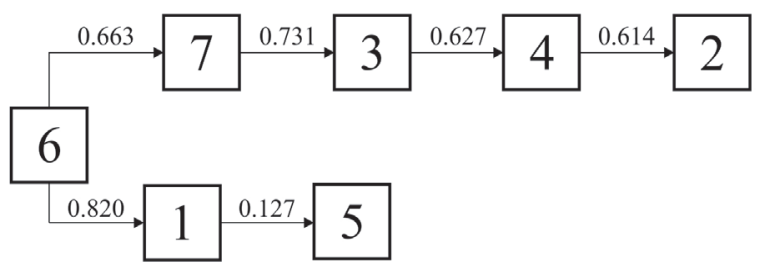

Source: Own source

At the model itself, the values of correlation coefficients among individual issues are provided, while the hierarchical relationships between them have not been taken into consideration yet. It is noted that certain issues have singled out as a separate group, i.e. clusters of individual groups of issues have been formed, referred to as cluster $\mathrm{C} 1$ and cluster C 2 (Figure 5).

Figure 5: Selected groups of questions in the form of clusters $C 1$ and C2

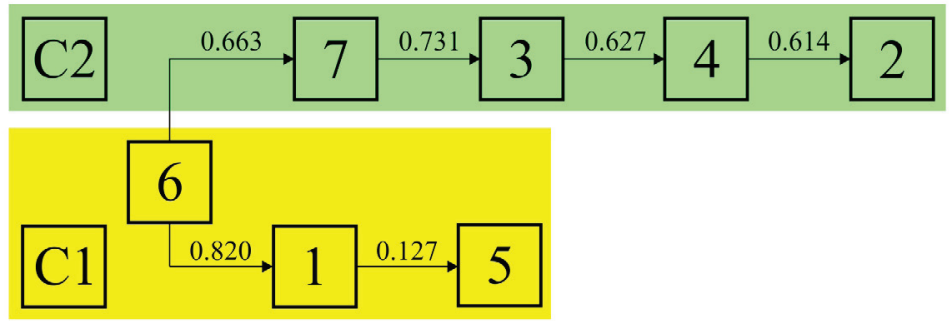

Source: Own source

On the basis of correlation coefficients in Table 2 as well as the models shown in Figures 4 and 5, the following hypotheses have been formed, ranked by the size of the mutual correlation coefficient (Table 3):

Table 3: Hypotheses formed on the basis of mutual correlation coefficients

\begin{tabular}{|c|c|l|}
\hline No. & Question & \multicolumn{1}{c|}{ Hypothesis } \\
\hline H1 & $6: 1$ & $\begin{array}{l}\text { introduction of modern technology and modern means of work is positively linked to an } \\
\text { increase in earnings }\end{array}$ \\
\hline H2 & $6: 7$ & $\begin{array}{l}\text { The introduction of modern technology and modern means of work is positively linked } \\
\text { to the desire of workers to be given better opportunities to participate in decision-making }\end{array}$ \\
\hline H3 & $7: 3$ & $\begin{array}{l}\text { The desire for greater worker participation in decision making is positively associated } \\
\text { with the desire to improve the existing protection programs }\end{array}$ \\
\hline H4 & $3: 4$ & $\begin{array}{l}\text { The desire to improve the existing protection programs is positively associated with } \\
\text { improving interpersonal relationships }\end{array}$ \\
\hline H5 & $4: 2$ & $\begin{array}{l}\text { Improving of interpersonal relationships was positively associated with the desire for new } \\
\text { protection programs }\end{array}$ \\
\hline H6 & $1: 5$ & $\begin{array}{l}\text { The increase in earnings was positively associated with the desire that the organization } \\
\text { shows more respect for the results of their workers }\end{array}$ \\
\hline
\end{tabular}


In order to create the final model of discussed organization issues that have the strongest correlation, the hypothesis H1-H6, are analyzed using Paired sample T test.

Table 4: Analysis of pairs of questions listed in Table 3, using Paired sample T test

\begin{tabular}{|c|c|c|c|c|c|c|c|c|c|}
\hline \multicolumn{10}{|c|}{ Paired Samples Test } \\
\hline & & \multicolumn{5}{|c|}{ Paired Differences } & \multirow{3}{*}{$\mathrm{t}$} & \multirow{3}{*}{$\begin{array}{l}\text { Corre- } \\
\text { lation }\end{array}$} & \multirow{3}{*}{ Sig. } \\
\hline & & \multirow[t]{2}{*}{ Mean } & \multirow[t]{2}{*}{$\begin{array}{c}\text { Std. } \\
\text { Deviation }\end{array}$} & \multirow[t]{2}{*}{$\begin{array}{l}\text { Std. } \\
\text { Error } \\
\text { Mean }\end{array}$} & \multicolumn{2}{|c|}{$\begin{array}{c}95 \% \text { Confidence } \\
\text { Interval of the } \\
\text { Difference }\end{array}$} & & & \\
\hline & & & & & Lower & Upper & & & \\
\hline Pair 1 & $6: 1$ & -1.098 & 1.426 & .105 & -1.305 & -.890 & -10.441 & .082 & .269 \\
\hline Pair 2 & $6: 7$ & .533 & 1.008 & .074 & .386 & 679 & 7.170 & .663 & .000 \\
\hline Pair 3 & $7: 3$ & -.283 & .939 & .069 & -.419 & -.146 & -4.083 & .731 & .000 \\
\hline Pair 4 & $3: 4$ & .293 & 1.072 & .079 & .138 & .449 & 3.715 & .627 & .000 \\
\hline Pair 5 & $4: 2$ & -.663 & 1.048 & .077 & -.816 & -.511 & -8.579 & .614 & .000 \\
\hline Pair 6 & $1: 5$ & .967 & 1.334 & .098 & .773 & 1.161 & 9.835 & .127 & .087 \\
\hline
\end{tabular}

The table clearly shows that only couples of questions $6: 1$ and 1:5 have a value greater than 0.05 , which means that the questions 6 and 1 , as well as questions 1 and 5 are at the same hierarchical level.

Based on the results, the final model was formed to consider the collective attitude of the organization on the issues set out in the questionnaire (Figure 6).

Figure 6: The final model hierarchy questionnaire

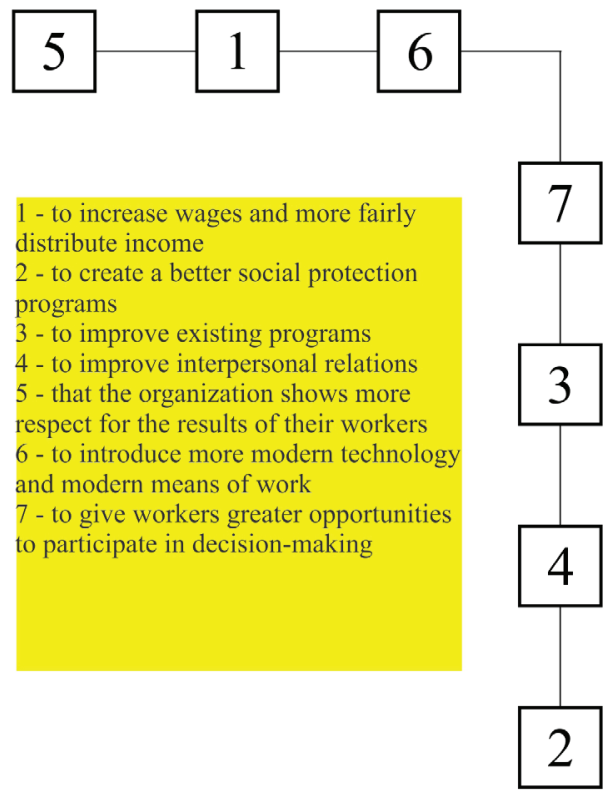

Source: Own source 


\section{Conclusion}

Based on the final hierarchy model questionnaire and the analysis of clusters $\mathrm{C} 1$ and $\mathrm{C} 2$, it is possible to conclude that the introduction of advanced technologies and modern means of work together with an increase in wages and fairer distribution of income have the greatest impact on workers' sense that organization shows respect for the results of their work, because, as it can be seen clearly on the created model, they are located at the same hierarchical level. This is quite logical, because the satisfaction of the employees with their work is best expressed through the amount of earning, but also, the amount of earning affects the quality of their work.

From the strength of the relationship between these issues and the same hierarchical level at which they are located, it can be concluded that, beside workers' material satisfaction, through which, in their opinion, the organization has showed more respect for their work, they extremely needed more modern means of work, as well.

Also, it can be concluded that the need of workers for the introduction of more modern technology and modernization funds for the work is directly related to the need of workers for greater participation in decision-making. From these connections there can be seen the need of workers for improving the working processes, as well as the organization itself. It can be concluded that workers, as active participants in the production process, feel neglected considering the issues related to the production process. In order to improve the working process, this situation must change because the workers are at the source of the problem and can provide a valuable assistance in identifying them, and in proposing measures for their elimination.

The need to improve the existing social protection programs is directly related to the need to improve interpersonal relationships, which in turn is directly related to the need to create new social protection programs. A serious work is needed for solving these problems but, of course, only after they have solved the problems that are at a higher hierarchical level.

\section{References}

Alderfer, C. (1972). Existence, Relatedness and Growth. New York, Free Press.

Arnolds, C.A, Vender, D.J.L. (2007): The strategic importance of motivational rewards for lower-level employees in the manufacturing and retailing industries, Journal of Industrial Psychology, 33(3): 15-23.

Bowlby, R. (2011). Living the Future: Organizational Performance Assessment, Journal of Library Administration, 51(7-8): 618-644.

Burney, L.L., Henle, C.A., Widener, S.K. (2009). A path model examining the relations among strategic performance measurement system characteristics, organizational justice, and extra and in-role performance. Accounting, Organizations and Society, 34(3-4): 305-321.

Cavazza, N., Serpe, A. (2009). Effects of safety climate on safety norm violations: exploring the mediating role of attitudinal ambivalence toward personal protective equipment. Journal of Safety Research 40: 277-283. 
Christian, M.S., Bradley, J.C., Wallace, J.C. and Burke, M.J. (2009). Workplace safety: A meta-analysis of the roles of person and situation factors. Journal of Applied Psychology, 94: 1103-1127.

Herzberg, F., Mausner, B., Snyderman, B. (1959). The Motivation to Work. New York: John Wiley \& Sons.

Kaplan, R.S., Norton, D.P. (1996). Performance Measurement and Control Systems for Implementing Strategy. Englewood Cliffs, NJ: Prentice Hall.

Latham, G.P., Locke, E.A., (1979). Goal setting: A motivational technique that works. Organizational Dynamics, 8(2): 68-80.

Lusthaus, C., Adrien, M.H, Anderson, G., Carden, F., Plinio, Montalván, G.P. (2002). Organizational Assessment: A Framework for Improving Performance, International Development Research Centre, Otawca, Canada and Inter-American Development Bank, New York, NY.

Maslow, A. (1943). A Theory of Human Motivation. Psychological review, 50(4): 370396.

McClelland, D. (1966). That Urge to Achieve. Think Magazine, November-December, pp. 19-23

McGregor, D. (1960). The Human Side of Enterprise. New York, McGraw-Hill.

Neal, A., Griffin, M. A. (2004). Safety climate and safety at work. In J. Barling \& M. R. Frone (Eds.), The psychology of workplace safety (pp. 15-34). Washington, DC: American Psychological Association.

Rakić, T. (2015). Occupational motivation and motivation for safe operation as one of the main objectives in HRM, in order to create more efficient and more pleasent working enviroment. In Ž. Živković (Ed.), XI International May Conference On Strategic Management - IMKSM 2015 (pp. 712-725). Bor: Technical Faculty in Bor.

Robbins, S. (2003). Organizational Behavior. Englewood Cliffs, N.J., Prentice-Hall.

Tissan, R., Andriesen, A., Depre, F.L. (2006). Dividenda znanja. Novi Sad: Adižes.

Williamson, A.M., Feyer, A.M., Cairns, D., Biancotti, D. (1997). The development of a measure of safety climate: the role of safety perceptions and attitudes. Safety Science 25: $15-27$

Wroom, V. (1964). Work and Motivation. Wiley, New York.

Živković, S. (2008). Motivation for occupational safety. Fakultet Zaštite na radu u Nišu, Niš. 